\title{
Analysis of Economic Benefits in Reclamation Activities and Coastal Conversion in Barru District
}

\author{
A. Muttia Yunita Mentari Sayuti
}

Department of fishery, Hasanuddin University. Makassar, Indonesia

\begin{abstract}
This research was conducted in Barru District, South Sulawesi. The purpose of this study is to analyze how much the total economic value of coastal land ecosystems in Barru District. Analyzing the value of economic benefits and the multiplier effects of coastal ecosystem reclamation activities in Barru District. Analysis of the data used is to use economic valuation analysis by calculating the value of direct benefits, indirect benefits, the value of option benefits, the value of the benefits of existence, and the value of bequeathing benefits. The results showed the total economic value in the Garongkong hamlet was Rp4,114,881,797 with an average value of Rp2,839,099,322, whereas for Lawallu village had a total economic value of Rp863,980,557 with an average value of Rp39,776,590. From these results, it can be seen that reclamation can provide a higher economic value compared to land conversion. With the reclamation, it can create opportunities for economic improvement of the community around the reclamation land.
\end{abstract}

Keywords- Mangrove Ecosystem, Value of Economic Benefits, Reclamation, Coastal area of Barru District.

\section{PRELIMINARY}

Indonesia is a country with the largest area of waters in the world, $75 \%$ of Indonesia's territory are oceans and the oceans have enormous economic potential for the development of the life of the Indonesian people and the improvement of Indonesia's welfare in general. The development of maritime territory for the last three decades has always been positioned as a periphery in national economic development. This condition is ironic considering that Indonesia's territory is very strategic in an important geo-political position namely the Pacific Ocean and the Indian Ocean where this region is the most dynamic region in the world political-economic arena. This makes Indonesia's marine potential should be the foundation of economic development.

Coastal is an area and ecosystem that is rich and potential to be used for various activities. The great potential becomes very important as the initial capital of development. Development is then directed at improving the people's welfare and social justice. On the other hand development must also continue to maintain the sustainability of the development itself, without damaging the functioning of the environmental ecosystem. Efforts to meet the needs and creation of an advanced economy on the one hand are very important, bearing in mind that macro economic progress is expected to encourage the creation of a prosperous society and ultimately a prosperous state. On the other hand economic development often ignores the functions of the surrounding environment. This condition causes damage to the ecosystem and leads to loss of resources (scarcity resources).

Barru District is located in the southern peninsula of Sulawesi Island, which is administratively part of the South Sulawesi Province, the area extending from North to South directly facing the Makassar Strait. Practically along the $\pm 72 \mathrm{~km}$ West side or about $22.4 \%$ of the total area of this district is a coastal area, with an altitude of 0-25 $\mathrm{m}$ above sea level (Anonymous, 2013; 2010). With such a geospatial position and configuration, the coastal and marine areas are the basis of natural resources which are the main components forming the basic character of society as well as socio-cultural, typological relations between regions and economic characteristics of the region. 
In 2013, a port was announced officially in Barru subdistrict, Barru District, South Sulawesi. The port has been built since 2015 by conducting reclamation activities. Reclamation is one of the potential solutions to increase demand for new land for living and development. In the past, many coastal countries, such as the Netherlands (Hoeksema, 2007), United Kingdom (OSPAR Commission, 2008), Japan (Suzuki, 2003), South Korea (Children and Wang, 2009) and Singapore (Glaser et al., 1991), have exploited Covers and reclaims the sea extensively (henceforth abbreviated as land reclamation) for the expansion of coastal cities, for land for industry and agricultural development along the coast, and also for defense against storm surges.

There are three objectives of the reclamation program are (Wagiu, 2011):

a) To get back the land lost due to the sea waves

b) To acquire new land in the front line of the coastline to erect a building that will function as a shoreline protection fortress

c) For economic reasons, construction or to erect large-scale building construction.

Conversion and the use of mangrove forests by cutting down forests and transferring their functions to other uses will have a very broad impact. Harvesting of forest products and conversion of mangrove forests can provide results to community income and opportunities to increase employment. But on the other hand, there was a decline in mangrove forests, which in turn could disrupt the surrounding aquatic ecosystem.

\section{METHOD}

Research activities on the reclamation and conversion of coastal land were performed in Barru District, taking two sub-districts of Barru District as research samples. This study took the location of reclamation and land conversion. For the reclamation area, it is located in the Garongkong Sea Port, precisely in the Garongkong neighborhood, Mangempang Village, Barru District, Barru District. For land conversion, the location is only in Lawallu Village, Soppeng Riaja District, Barru District. This research was conducted for 3 months.

\section{Data collection}

Based on the research objectives, the data collected in this study consisted of two sources, namely primary data and secondary data. Primary data, i.e. data obtained directly from measurements and observations in the field. This primary data is sourced from coastal locations, fishermen or farmers, tourists, the general public, and stakeholders who have an interest in coastal ecosystems. Secondary data, namely supporting data collected from departmental, government and private agencies, as well as from publications and research results that have been carried out previously.

\section{Economic Valuation Analysis}

Generally, assessments occur based on interactions between humans as subjects (assessors) and objects (something that is valued). Each individual has a different perspective in assessing things. Every individual has a number of values that are said to be the value of mastery (head value) which is the basis of individual preferences. In the end the value of the object is determined by the various values that are stated (assigned value) by individuals (Pearce and Turner, 1994 in Djijiono 2002).

$$
\mathrm{TEV}=\mathrm{DV}+\mathrm{IV}+\mathrm{OV}+\mathrm{EV}+\mathrm{BV}
$$

Remaks:

$\mathrm{TEV}=$ Total economic value

$\mathrm{DV}=$ Value of direct benefit

$\mathrm{IV}=$ Value of indirect benefit

$\mathrm{OV}=$ Value of option benefit

$\mathrm{EV}=$ Value of existence benefit

$\mathrm{BV}=$ Value of bequeathing benefit

Each of these values is identified based on all the benefits gained in the mangrove ecosystem studied. Each of these values is as follows:

\section{a. Direct Use Value (DUV)}

The formula used to get the total value of direct benefits is according to the following:

$\mathrm{TML}=\mathrm{ML1}+\mathrm{ML} 2+\mathrm{ML} 3+\ldots+\mathrm{MLn}$

Where :

$\mathrm{TML}=$ Total Direct Benefits

ML1 = Direct Benefits of Fish

ML2 = Direct Benefits of Crabs

ML3 = Direct Benefits of Shells

ML4 = Direct Benefits of Mangrove Wood

b. Indirect Benefits

Value of indirect benefits is the value of benefits from a resource (mangrove) that is used indirectly by the community. Indirect benefits of mangrove forests can be in the form of physical benefits, namely as a barrier to seawater abrasion. Physical assessment of mangrove forests can be estimated by the function of mangrove 
forests as abrasion, feeding, spawning, and nursery ground protection. However, in this study the value of indirect benefits is only approached by using the function of mangrove forests as a barrier to abrasion. Other indirect functions require comprehensive research given the limited availability of data.

c. Option Benefits

The formula is as follows:

$$
\begin{aligned}
& \text { MP = MPPL } \\
& \text { Where : } \\
& \text { MP = Benefits of option } \\
& \text { MPPL = Benefits of other usage options }
\end{aligned}
$$

d. Existence Benefits

These benefits can be formulated as follows (Ruitenbeek, 1992):

$$
\mathrm{ME}=\sum_{i=1}^{n}(\mathrm{MEi}) / n
$$

explanation:

$\mathrm{ME}=$ Benefits of Existence

$\mathrm{MEi}=$ Ecosystem benefits from the i-respondent

$\mathrm{N}=$ Number of respondents

e. Bequeathing Benefits

The formula is as follows :

$$
\mathrm{ME}=\sum_{i=1}^{n}(\mathrm{MKi}) / n
$$

Where :

MW = the benefits of bequeathing

Mwi = benefit of bequeathing from the i-respondent $\mathrm{N}=$ total respondents

\section{Analysis of WTP with CVM}

According to Juanda (2009), multiple linear regression analysis (multiple regression) is a regression equation that describes the relationship between one dependent variable (dependent variable) with several independent variables. Multiple linear regression analysis in this study was used to evaluate the use of contingent valuation method (CVM). Evaluation of the implementation of the CVM model can be seen from the level of reliability of the willingness to pay (WTP) function. The multiple linear regression equation used in analyzing the factors that influence the WTP value of respondents is as follows:

$\mathrm{WTP}=\beta 0+\beta 1 \mathrm{JK}+\beta 2 \mathrm{TP}+\beta 3 \mathrm{PD}+\beta 4 \mathrm{PK}+\beta 5 \mathrm{JT} \ldots+$ $\beta \mathrm{nXY}+\varepsilon \mathrm{i}$

Where :

$\mathrm{JK}=\mathrm{Sex}($ Women and Men)
$\mathrm{TP}=$ Education Level

$\mathrm{PD}=$ Revenue

$\mathrm{PK}=\mathrm{Work}$

JT $=$ Number of Dependents

$\varepsilon=$ Error

$\mathrm{I}=$ First Respondent $(\mathrm{i}=1,2,3, \ldots \mathrm{n})$

3. Analysis of the economic benefits of conversion and reclamation

The economic impact of land conversion and reclamation is measured using the multiplier effect of the cash flows that occur. In measuring the economic impact of an activity on a community's economy, it is analyzed by dynamic modeling through the dynamics of inter-relations between vital elements along with the changing time of the ecological-economic system examined in this study. The basic concept of the formulation of the model refers to the cyclic effect where changes in the index and management attributes can affect the sustainability of the marine tourism management system. The analysis stage begins by building a causal loop diagram, then making a model base, entering the attribute values that have been obtained in the previous analysis into the model that was built, arranging the management model scenario, and finally doing a model simulation. The attribute values used in analyzing the sustainability of management are derived from the results of previous analyzes, namely land suitability analysis, area carrying capacity analysis, economic valuation of coral reef and mangrove resources, cost-benefit analysis, and literature search. Some attribute values used are obtained from scientific estimation methods, but it is recognized that the accuracy of parameter estimates depends on the availability of data from the source and the analytical method used.

Measurement of local economic impacts through several types of multiplier effects (META, 2001), namely:

Keynesian Income Multiplier is a change in tourist expenditure units giving changes to the income level of local people. Mathematically written:

$$
=\frac{D+N+U}{E}
$$

Ratio Income Multiplier is a multiplier effect that illustrates how much impact on the local economy. This multiplier has included further impacts and indirect impacts.

Ratio Income Multiplier Type I, mathematically written: 


$$
=\frac{D+N}{D}
$$

Ratio Income Multiplier Type II, mathematically written:

$$
=\frac{D+N+U}{D}
$$

Where:

D: Local income received directly from E (rupiah)

$\mathrm{N}$ : Local income received indirectly from $\mathrm{E}$ (rupiah)

E: Additional tourist expenditure (rupiah)

$\mathrm{U}$ : Local income received further from $\mathrm{E}$ (rupiah)

The multiplier effect has the following criterias :

- If the multiplier coefficient value is less or equal to zero $(\leq 0)$, then the reclamation and land conversion area has not been able to have an economic impact on community activities.

- If the multiplier coefficient value is between zero and one $(0 \leq \mathrm{x} \leq 1)$, then the reclamation and land conversion area has a low economic impact value.

- If the multiplier coefficient is more than or equal to one $(\geq 1)$, the reclamation and land conversion area is able to have an economic impact on tourism activities.

\section{RESULTS AND DISCUSSION}

\section{The Direct Benefits of Mangrove Resources}

Barru coastal mangrove resources have a variety of benefits, both directly and indirectly. The direct benefit of mangrove resources in Barru District can be seen in the direct use of fisheries resources that exist around the mangrove forest.

The value of direct benefits is the value or benefits of mangrove forest resources obtained directly through their production and consumption. Direct benefits for the community from mangrove forests in the study area are firewood, nipa roofs, fish and crabs. Benefits are staple foods for fish, shrimp, and crabs that live in coastal ecosystems through landslides from mangrove litter (especially their leaves). A small amount of waste falls on the forest floor will be consumed by crabs and most will be decomposed by microbes that are the source of detrivora food, then detrivora becomes a source of carnivorous food (Harahap 2010; Kusmana 2010). Another benefit obtained from the mangrove ecosystem is abundance is an aquatic biota that is economically valuable. There are several types of aquatic biota around mangroves that can and are often utilized by the community including baronang fish, white grouper fish, besides that there are also tude oysters and squid.

Table 2. Total Value of Mangrove Benefits in Garongkong and Lawallu Villages

\begin{tabular}{lclll}
\hline \multirow{2}{*}{ Type } & \multicolumn{2}{l}{ Total Value of Benefits } & Average Benefits & \\
\cline { 2 - 5 } & Garongkong & Lawallu & Garongkong & Lawallu \\
\hline $\begin{array}{l}\text { Fishe } \\
\text { s }\end{array}$ & 1.241 .155 .366 & $\begin{array}{l}428.261 . \\
627\end{array}$ & $33.544 .739,62$ & $\begin{array}{l}26.766 .3 \\
51\end{array}$ \\
Squi & 67.540 .000 & - & $22.513 .333,33$ & - \\
ds & & & & \\
Crab & 4.400 .000 & 16.120 .0 & 4.400 .000 & $\begin{array}{l}\text { ( } 060.00 \\
\text { s }\end{array}$ \\
Woo & 400.1400. & 400.1400 .00 & & 0 \\
ds & 000 & 0 & 527.889 & 527.889 \\
\hline Total & $\mathbf{1 . 3 2 8 . 6 2 3 . 8}$ & & $\mathbf{6 0 . 9 8 5 . 9 6 1 ,}$ & $\mathbf{3 5 . 3 5 4 . 2}$ \\
& $\mathbf{4 2}$ & $\mathbf{8 4 4 . 5 2 1 . 6 2 7}$ & $\mathbf{9 5}$ & \\
\hline
\end{tabular}

Source : Primary Data, 2018

The measurement of direct benefits is carried out in terms of market value in order to quantify the prices of various charcoal obtained. The process of calculating the value of direct benefits of a mangrove ecosystem is done by multiplying the average net income by the total population. Net income is obtained from the selisis between the total gross income with the total costs used to obtain these resources. Total gross income derived from production is multiplied by price.

\section{Value of Benefits of Direct Fishing}

Barru District is a district in Barru District which has a height of $6 \mathrm{~m}$ above sea level. The total population in Barru Subdistrict is 5,791 people in 2018. Barru Subdistrict has 5 villages and 5 villages, one of which is Mangempang Village. Mangempang Urban Village has an area of $13.8 \mathrm{Km} 2$ and is one of the coastal areas in Barru District. This causes some residents to choose to work as fishermen. The work is used as a livelihood in supporting increased production in the fishing sector. (BPS Kab Barru, 2019)

Soppeng Riaja sub-district in Barru District has 5 villages and 2 kelurahan, one of which is Lawallu. Lawallu Village has a population of 1,966 people. Lawallu Village has the potential for development related to businesses in the fisheries and marine sector. The characteristic of this area which is a coastal area is the dominant profession of the community earning a living as a fisherman. Nevertheless in this Lawallu village there are also several other potentials to be developed. The many mangrove forests on the coast of Lawallu Village have high economic value. (BPS Kab Barru, 2019). 
Fishing is performed in the mangrove area around the Garongkong Hamlet and Lawallu Village. The type of fishing gear that is used to catch fish in the Garongkong hamlet and Lawallu Village uses the same fishing gear that is a net. The fish catches produced consist of various types of fish namely Cepak for Garongkong Hamlet,Gembong and Kakap for Lawallu Village. How to calculate the number of catches is by hanging (per-hanging), not using per $\mathrm{kg}$ in one time catches.

For Garongkong Hamlet, the fishes caught are Cepak. The average number of catches of Cepak is 845 hanging / year. The average selling price of Cepak from fishermen to collectors is Rp.47,027 / hanging. The number of fishermen who catch in the mangrove area around Garongkong are 37 people.

The total costs incurred in the catching of Cepak Fish business are Rp231,359,634 / year, including an investment cost of Rp436,510,000 / year. Based on the amount of production, the selling price of fish and the costs incurred for catching, the net benefit value from catching fish will be obtained in the amount of Rp1,241,155,366 / year.

For Lawallu Village, the fishes caught are Kakap and Gembong. The average number of fish caught is 744 hanging / year. The average selling price for Kakap and Gembong is IDR 45,625 / hanging. In the calculation of fish catches for the village of Lawallu combined because there is no difference in the selling price of fish to collectors. The number of fishermen who catch in the mangrove forest area around the land conversion area are 16 people.

The total costs incurred in the fishing business in the hamlet of Lawallu is Rp.115,248,373 / year, with investment costs in the fishing business amounting to Rp138,171,000 / year. Based on the amount of production, sales price and cost of catching, the net benefit value from catching Kakap and Gembong fishing is Rp. 428,261,627 / year.

The frequency of catching for Garongkong subvillage is an average of 247 fish catches a year and for Lawallu Village is around 232 times a year. Catching is done once a day to catch fish. The number of catches obtained in a year for Garongkong Hamlet is an average of 845 catches per year, while for Lawallu Village which is an average of 744 catches. For the selling price, for Garongkong hamlet, the average selling price of fish is IDR 47,027 / stick and for Lawallu Village which is around IDR 45,625. Based on this value, the total economic value of fish obtained by Garongkong Hamlet is in the amount of Rp1,241,155,366 / year and for Lawallu Village in the amount of IDR428,261,627 / year.

\section{The Direct Benefits of Squid}

Catching squids is performed by fishermen in the Garongkong hamlet using fishing nets. Theydon't consider catching squid as priority because squids are not available every day. There are 4 cumu-squid catchers in Garongkong village. Costs incurred to catch squid is Rp13,486,000 / year.

The catch a day reaches an average of 3 hanging per day and 2,228 hanging / year with a selling price of Rp 50,000 / hanging. Squid will be sold to collectors or sold directly to the market. The net catch of squid in a year is Rp100,914,000 / year.

\section{Value of Direct Benefits of Crab Catching}

The types of crabs caught by the community in the mangrove forest area in Garongkong and Lawallu villages are mangrove crabs. Mangrove crabs have habitats and live in holes and thickets of mangrove trees, while crab crabs live in coastal areas around mangrove forests.

The fishing gear used by crab catchers in the mangrove area of Garongkong and Lawallu Village uses the same tool, which is a trap made of bamboo or rattan. The number of fishermen who caught crabs in Garongkong sub-village was 1 person and in Lawallu village was 2 people. The total cost used for crab fishing in Garongkong is IDR 6,633,000 / year. For Lawallu Village, the cost of arrest is Rp14,909,835 / year.

Based on the results of interviews with respondents from each region that in one year, fishermen catching mangrove crabs in Garongkong area were performed as many as 176 days of fishing with a catch of around $2 \mathrm{~kg} /$ day. The total number of catches of mangrove crabs in one year reaches $176 \mathrm{~kg} /$ year, so the net income value of mangrove crab catchers in the Garongkong hamlet in the mangrove forest area is Rp.4,400,000 / year.

As for calculating the direct benefits of crabs in Lawallu Village, in one year, fishermen catch mangrove crabs for 471 days. The catch per day can reach $3 \mathrm{~kg} /$ day. The total catch of mangroves in a year reaches 484 $\mathrm{kg} /$ year. Net income from the catching of crabs in Lawallu Village is IDR 16,120,000 / year.

\section{Value of Benefits of Collecting Firewood}

Utilization of mangrove branches and twigs for firewood as a source of energy is usually done by 
people who live or live around mangrove forests. At present the value of using mangrove wood, which is usually used as firewood, is no longer used by the people of Garongkong and Lawallu villages. This happens because of the awareness of the community or the community to obey the rules set by the Barru District government that the community is prohibited, cut or take wood from mangrove trees. In this research, the value of mangrove wood utilization is still calculated so that the community can compare the value of the use of wood used as firewood by stabilizing the value of using mangrove wood into firewood from other areas close to this research area.

In the Tahang study (2018), the community in Sinjai District still had a community that used mangrove wood as firewood. The economic value of mangroves for firewood is derived from the amount of firewood used by household rumors that are used instead of oil stoves or gas stoves. In the study, for areas that, as mangrove wood as firewood, were still in the area of East Sinjai, it was assumed that the number of households using firewood was $10 \%$ of the total respondents (KK) of 350 households. Umlah it could have been smaller or larger than what happened in the field. According to the results of surveys and interviews conducted by researchers, the amount obtained in collecting firewood for consumption as a substitute fuel is IDR 95,000. thus the value of mangroves for firewood in the eastern Sinjai mangrove forest area is Rp.400,400,000 per year.

\section{Indirect Benefits of Mangrove Resources}

Indirect benefits are values that indirectly feel benefits, can be in the form of things that support direct use value. Indirect benefits of mangrove forests in Barru District are physical and biological benefits. Indirect physical benefits are as a barrier to coastal abrasion which is estimated through replacement cost by making beach concrete for break water. The results obtained are based on the replacement cost of the breakwater value, referring to the estimation made by Aprilwati (2001), namely that the cost of constructing a breakwater 'size 1 $\mathrm{mx} 11 \mathrm{mx} 2.5 \mathrm{~m}$ (length $\mathrm{x}$ width $\mathrm{x}$ height) with 10 year endurance of Rp4,153,880.00.

For the Garongkong region, making waves holds using materials such as cement, rock, sand and concrete steel. Costs incurred for making waves or break water in the Port of Garongkong, Garongkong Village amounting to $\mathrm{Rp} 17,570,176.18$. The average break water height in Garongkong Village is around 2.5 meters.
Value of indirect benefits $=1,581 \mathrm{~m} \mathrm{x}$ Rp17,570,176.18

$=\operatorname{Rp} 27,778,448,548 .-$ Or

$=$ Rp. 2,777,844,855/year

The indirect benefits of mangroves as a barrier to the waves

\section{Benefits of Options}

The benefits of choice are approached by the value of biodiversity (biodiversity). According to Suryono (2006), the choice of benefits is a type of utilization that reflects the value of biodiversity (biodiversity) that can be captured from the presence of mangrove forests. The choice value is estimated based on the biodiversity value provided by the mangrove forest ecosystem according to the results of Ruitenbeek (1992) in Rivalda (2017), which is US \$ 1,500 / Km2 / Year or US \$ 15 / Ha / Year or Rp223,770 / Ha / year (US $\$ 1=$ Rp. 14,918 at the time of the study). The value of selected mangrove forest ecosystems in Garongkong and Lawallu Villages can be explained in the table:

Table 3. Benefits of Mangrove Options in Garongkong Hamlet and Lawallu Village

\begin{tabular}{llll}
\hline $\begin{array}{l}\text { Research } \\
\text { Location }\end{array}$ & $\begin{array}{l}\text { Biodiversity } \\
\text { value(Rp/Ha/Year }\end{array}$ & $\begin{array}{l}\text { The large } \\
\text { of } \\
\text { Magrove } \\
\text { s forests }\end{array}$ & $\begin{array}{l}\text { Value of } \\
\text { Option }\end{array}$ \\
\hline Garongkon & 223,770 & 30 & $6,713,100$ \\
g & 223,770 & 65 & $\begin{array}{l}14,545,05 \\
0\end{array}$ \\
Lawallu & $\mathbf{2 2 3 , 7 7 0}$ & $\mathbf{9 5}$ & $\mathbf{2 1 , 2 5 8 , 1 5 0}$ \\
Total & $\mathbf{2 2 3 , 7 7 0}$ & $\mathbf{4 7 . 5}$ & $\mathbf{1 0 , 6 2 9 , 0 7 5}$ \\
\hline Average & & &
\end{tabular}

Source : Primary Data, 2018

The table above shows that Garonkong Hamlet has a chosen value of IDR 6,713,000 per year. While the value of choice for the village of Lawallu is Rp14,545,050. The difference in the value of choice between the two locations is due to the difference in the size of the mangrove forest area, where Lawallu village has a larger area of mangrove forest compared to Garongkong Hamlet. which is $65 \mathrm{Ha}$. In contrast, the mangrove forest in Garongkong Hamlet is the smallest area with an area of only 30 hectares of mangrove forest.

\section{Benefits of Existence}

The benefits of the existence of mangrove forests in Garongkong Hamlet and Lawallu Village, are obtained by valuation techniques based on surveys to find out the 
willingness to pay or community WTP (Willingnes to Pay). Based on the results of interviews with the responbden, it is known that those who use mangrove forests directly are those who work as fishermen with the ability to pay around Rp. 40,000 to Rp. 50,000 per year. The results of interviews and surveys in Garongkong and Lawallu Villages are tabulated to get the total value of PAPs, average and value of existence benefits per individual per year and value of existence benefits per year

Table 4. Benefits of the existence of Mangroves in Garongkong and Lawallu Villages

\begin{tabular}{lll}
\hline $\begin{array}{l}\text { Respondent } \\
\text { Indicator }\end{array}$ & $\begin{array}{l}\text { Garongkong } \\
\text { Hamlet }\end{array}$ & $\begin{array}{l}\text { Lawallu } \\
\text { Village }\end{array}$ \\
\hline $\begin{array}{l}\text { Respondent } \\
\text { Large }\end{array}$ & 38 & 17 \\
$\begin{array}{l}\text { Mangrove } \\
\text { firewoods }\end{array}$ & 30 ha & 65 ha \\
\hline $\begin{array}{l}\text { Total Value } \\
\text { WTP }\end{array}$ & Rp1.700.000 & Rp760.000 \\
\hline Average WTP & Rp44.736 & Rp44.705 \\
\hline Souce: Primary Data, 2018 &
\end{tabular}

The table above shows that respondents from Garongkong sub-village have the highest value of being Rp.1,700,000 per year with an average PAP value of Rp.44,736. Whereas for Lawallu Village, it has a low existence value of IDR760,000 per year with an average WTP value of IDR44,705. the difference between the number of PAPs in the two locations is based on the highest number of families or households directly utilizing the mangrove forest as a place to make a living. Garongkong Hamlet has 38 families who directly utilize mangrove forests, while in Lawallu Village there are 17 households who use mangrove forests directly.

\section{Total Economic Value}

The results of the identification and calculation of all benefits are the total economic value obtained from the mangrove forests in the Garongkong and Lawallu villages. Identification of the benefits obtained in this study include direct benefits, indirect benefits, benefit benefits, and the benefits of existence. The direct data found in both locations are the direct benefits of fisheries (fish, crabs, and squid). Indirect benefits calculated are ecological benefits (as a breakwater).
Table 5. Total Economic Value of Garongkong Hamlet and Lawallu Village

\begin{tabular}{|c|c|c|c|c|}
\hline \multirow[b]{2}{*}{ type } & \multicolumn{2}{|c|}{ Total Value of Benefits } & \multicolumn{2}{|c|}{ Average Benefits } \\
\hline & $\begin{array}{l}\text { Garongko } \\
\text { ng }\end{array}$ & Lawallu & $\begin{array}{l}\text { Garongko } \\
\text { ng }\end{array}$ & Lawallu \\
\hline $\begin{array}{l}\text { Direct } \\
\text { Benef } \\
\text { its }\end{array}$ & $\begin{array}{l}1,328,623,8 \\
42.00\end{array}$ & $\begin{array}{l}844,521,6 \\
27.00\end{array}$ & $\begin{array}{l}60,985,961 . \\
95\end{array}$ & $\begin{array}{l}35,354,2 \\
40.00\end{array}$ \\
\hline $\begin{array}{l}\text { Indire } \\
\text { ct } \\
\text { Benef } \\
\text { its }\end{array}$ & $\begin{array}{l}2,777,844,8 \\
55.00\end{array}$ & $\begin{array}{l}4,153,880 . \\
00\end{array}$ & $\begin{array}{l}2,777,844,8 \\
55.00\end{array}$ & $\begin{array}{l}4,153,88 \\
0.00\end{array}$ \\
\hline $\begin{array}{l}\text { Optio } \\
\mathrm{n} \\
\text { Benef } \\
\text { its }\end{array}$ & $\begin{array}{l}6,713,100.0 \\
0\end{array}$ & $\begin{array}{l}14,545,05 \\
0.00\end{array}$ & $223,770.00$ & $\begin{array}{l}223,720 . \\
00\end{array}$ \\
\hline $\begin{array}{l}\text { Existe } \\
\text { nce } \\
\text { Benef } \\
\text { its }\end{array}$ & $\begin{array}{l}1,700,000.0 \\
0\end{array}$ & $\begin{array}{l}760,000.0 \\
0\end{array}$ & $44,736.00$ & $\begin{array}{l}44,750.0 \\
0\end{array}$ \\
\hline Total & $\begin{array}{l}4,114,881,7 \\
97.00\end{array}$ & $\begin{array}{l}\mathbf{8 6 3 , 9 8 0 , 5} \\
\mathbf{5 7 . 0 0}\end{array}$ & $\begin{array}{l}2,839,099,3 \\
22.95\end{array}$ & $\begin{array}{l}39,776,5 \\
90.00\end{array}$ \\
\hline
\end{tabular}

Source : Primary Data, 2018.

Based on the table above shows the total economic value in the two regions, namely Garongkong Hamlet and Lawallu Village. In Garongkong Hamlet, the total economic value obtained is IDR 4,144,881,797 with an average benefit of IDR 2,839,099,322.95. Whereas for Lawallu Hamlet, the total economic value obtained is IDR863,980,557 with an average total economic benefit of IDR39,776,590.

\section{Multiplier Effect}

Garongkong seaport / bulk port is the construction of Makassar's main port which is projected as a non-food dry bulk port such as cement, coal, clinker, etc., and the liquid bulk terminal. Before the loading / unloading activity of non-food dry bulk was in Soekarno Harbor, Makassar. Non-food dry bulk unloading activities will be moved from those originally located at Soekarno Port to Garongkong with the aim that the activity of loading and unloading existing dry bulk food (wheat flour, etc.) is separated from the activity of loading and unloading non-dry bulk food (cement, etc.) so as to produce healthier products and environments.

The port activities have an economic impact on the people who live or live near the port. The impact obtained by the community is the improvement of the road to the port. The road is the first road that provides access to the port, through the local residents before 
making a road that connects directly to the trans Sulawesi road. In addition to road improvements, the port has another impact on society, namely the opening of employment opportunities. Open employment opportunities are as a docker and business opportunities are open such as grocery stores that are open around the port area.

\section{Direct Impact}

The direct impact is the total Non-Tax State Revenue (PNBP) obtained from the Garongkong port. Non-Tax State Revenues (PNBP) consist of several types of deposits, namely Sign / Navigation Services, Shipping Services, Ports Services, and the last one is Sea Transportation Services. In the services of signs / navigation total revenue in 2017 that is $\operatorname{Rp} 257,366,748$. For shipping services, the total revenue generated by the Garongkong port is Rp39,329,811. As for port services, total revenues in the year amounted to Rp2,368,627,666. As for sea transportation services, the total revenue generated for the Garongkong port is Rp54,016,364. The total of each deposit included in the Non-Tax State Revenue (PNBP) in 2017 is IDR 2,219,340,589.

\section{Indirect Impact}

The indirect impact is the wage of labor obtained from the loading and unloading activities of ships leaning at the Port of Garongkong. Workers at the Port of Garongkong numbered 105 people and as many as 53 respondents were respondents. Workers are divided into 6 groups and each group consists of 17-18 people. Work is divided into three shifts in one day, i.e. the first shift is at $08.00-16.00$, for the second shift at $16.00-00.00$, and the third shift at $00.00-08.00$. The labor employment system at the Garongkong Port is using a wholesale system. Workers' wages or salaries will be given equally to each group and the group leader will share equally with the workers who were present at that time. The number of opinions or labor costs is IDR $38,700,000$ with an average monthly wage of IDR 730,188 .

\section{Subsequent Impact}

Follow-up impacts are exchanges issued by workers as cash flows obtained from direct and indirect impacts. The expenditure consists of labor expenses while working at the port location. Costs incurred for consumption costs amounted to Rp1,486,000 per month with an average expenditure of Rp.43,705 per month. Expenditures for consumption are only in the form of cigarettes and only 34 people consume cigarettes while working. For the consumption of lunch and dinner while working at the Port, workers choose to eat at their respective homes for their expenses. For coffee and mineral water while working, all are borne or have been provided by the company.

\section{Multiplier Effect Results}

The Multiplier Effect is used to calculate the economic impact caused by reclamation in Garongkong. Calculation of the Multiplier Effect can be seen in the appendix:

Table 6. Multipler Effect

\begin{tabular}{|c|c|c|}
\hline Kriteria & Nilai & Keterangan \\
\hline $\begin{array}{l}\text { Keynesian Income } \\
\text { Multiplier }\end{array}$ & 3.07 & $\begin{array}{l}\text { Economic impacts that } \\
\text { occur provide a large } \\
\text { economic impact on } \\
\text { reclamation activities } \\
\text { because the value of the } \\
\text { Keynesian Income } \\
\text { Multiplier obtained is } \\
\text { greater than } 1(\geq 1) \text {. }\end{array}$ \\
\hline $\begin{array}{l}\text { Ration Income } \\
\text { Multiplier I }\end{array}$ & 1.01 & $\begin{array}{l}\text { The economic impact is said } \\
\text { to have a large impact }\end{array}$ \\
\hline $\begin{array}{l}\text { Ratio Income } \\
\text { Multiplier II }\end{array}$ & 1.01 & $\begin{array}{l}\text { because the value of Ration } \\
\text { Income Multiplier I and } \\
\text { Ratio Income Multiplier II is } \\
\text { greater or equal to one }(\geq 1) \text {. }\end{array}$ \\
\hline
\end{tabular}

Source: Primary Data, 2018

Based on the calculation of the results of the multiplier, the economy of reclamation provides a real and large economic impact seen from Keynesian Income Multiplier, Ratio Income Multiplier I, and Ratio Income Multiplier II which are quite high. The Keynesian Income Multiplier result of 3.07 means an increase in spending every Rp10,000, will increase Garongkong Port revenue and labor costs by Rp30,700. While the results of the Ratio Income Multiplier I of 1.01, which means increasing the income of the Garongkong Port by Rp10,000, will increase labor income by $\mathrm{Rp} 10,100$. The results of the Ratio Income Multiplier II of 1.01, which means an increase in income of the Garongkong Port by Rp10,100, will have an impact on direct impacts, indirect impacts, and subsequent impacts (Garongkong Port revenue, labor wages, and consumption expenses) by Rp10,100.

\section{CONCLUSION AND RECOMMENDATION}

\section{Conclusion}

The conclusions from the results of research on the analysis of economic benefits in the activity of 
reclamation and conversion of coastal land in Barru District are as follows:

1) The total economic value in the Garongkong hamlet is Rp4,114,881,797 with an average value of Rp2,839,099,322, while for Lawallu village it has a total economic value of $\mathrm{Rp} 863,980,557$ with an average value of $\mathrm{Rp} 39,776,590$.

2) The economy from reclamation has a real and large economic impact seen from Keynesian Income Multiplier, Ration Income Multiplier I, and Ratio Income Multiplier II which are quite high. The result of Keynesian Income Multiplier is 3.07. The result of Ratio Income Multiplier I is 1.01 and the Result Ratio Income Multiplier II is 1.01.

From the results of the calculation of the total economic value, the value of economic benefits and the Multipler Effect, it can be concluded that the reclamation activity can have a positive impact on the economic improvement of the community around the reclamation area.

\section{Recommendation}

Considering that reclamation is more profitable than land conversion, the government should pay more attention in the form of socialization, providing counseling to communities around the reclamation area to be able to improve the economy by utilizing available resources. Provision of assistance in the form of capital to provide production facilities for business development can be done by the local government.

\section{REFERENCES}

[1] Anonim. (2013). Penyusunan Rencana Induk (Master Plan) Kawasan Minapolitan Kabupaten Barru. Dinas Kelautan dan Perikanan Kabupaten Barru, 207 hlm.

[2] Baderan, Dewi Wahyuni K. 2013. Model Valuasi Ekonomi Sebagai Dasar Untuk Rehabilitasi Kerusakan Hutan Mangrove Di Wilayah Pesisir Kecamatan Kwandang Kabupaten Gorontalo Utara Provinsi Gorontalo .http://etd.repository.ugm.ac.id/index.php?mo $\underline{\mathrm{d}=\text { penelitian_detail\&sub=PenelitianDetail\&act=view\&ty }}$ $\mathrm{p}=\mathrm{html} \&$ buku_id=58942 (AccessedDecember 4th, 2017 at 20.34).

[3] Dijiono. 2002. Valuasi Ekonomi Menggunakan Metode Travel Cost TamanWisata Hutan di Taman Wan Abdul Rachman, Propinsi Lampung.Makalah Pengantar Falsasah Saint Program Pasca Sarjana Intiut Pertanian Bogor, Bogor

[4] Dreze, J. dan Stern, N. 1987. Chapter 14 The theory of cost-benefit analysis. Handbook of Public EconomicsVolume 2, 1987, Pages 909-989. London School of Economics.
[5] Efendi, Y. 2016. Upaya Konservasi Ekosistem Mangrove Berbasis Kemandirian Masyarakat Di Wilayah Pesisir Batam. academia.edu

[6] Fathurrohmah, Septiana. 2013. Aplikasi Penginderaan Jauh Untuk Pengelolaan Hutan Mangrove Sebagai Salah Satu Sumberdaya Wilayah Pesisir (Studi Kasus Di Delta Sungai Wulan Kabupaten Demak). ISBN: 978-979-636152-6. Seminar Nasional Pendayagunaan Informasi Geospatial Untuk Optimalisasi Otonomi Daerah 2013

[7] Juanda B. (2009). Ekonometrika Pemodelan dan Pendugaan. Bogor: IPB Press.

[8] Kusmana, C. 1997. Metode Survey Vegetasi. Bogor: Penerbit Institut Pertanian Bogor

[9] Kay, R. dan Alder, J. 1999. Coastal Management and Planning. E \& FN SPON. New York.

[10] Kawulusan, B. 2016. ANALISIS MANFAAT DAN BIAYA (COST AND BENEFIT ANALYSIS). http://boviekawulusan.blogspot.co.id/2016/01/analisismanfaat-dan-biaya-cost-and.html. (diakses pada tanggal 18 Januari 2018 Pukul 03.51).

[11] Lo, K. F. A. dan Gunasiri, C. 2014. Impact of Coastal Land Use Change on Shoreline Dynamics in Yunlin County, Taiwan. Environments 2014, 1, 124-136;

[12] [META] Marine Ecotourism for Atlantic Area. 2001. Planning for MarineEcotourism in The Eu Atlantic Area. Britol (GB): University of The West Of England.

[13] ,Nurfiarini, A. (2003). Kajian Pengembangan Budidaya Perikanan Pesisir Dan Pengaruhnya Terhadap Kondisi Sosial Ekonomi Masyarakat Di Teluk Saleh Kabupaten Dompu. Bogor: IPB Bogor. Tesis tidak dipublikasikan.

[14] Nurmandi, A., (1999), Manajemen Perkotaan: Aktor. Organisasi dan Pengelolaan DaerahPerkotaan di Indonesia. Lingkaran Bangsa:Yogyakarta

[15] Rachman, M. 2012. Konservasi Nilai Dan Warisan Budaya. https://journal.unnes.ac.id/nju/index.php/ijc/article/viewF ile/2062/2176

[16] Siregar, Parpen. 2009. Konservasi sebagai Upaya Mencegah Konflik Manusia-Satwa. Jurnal Urip Santoso. http:// uripsantoso.wordpress.com

[17] Supriharyono. 2000. Pelestarian dan Pengolahan Sumberdaya Alam di Wilayah Pesisir Tropis. Gramedia:Jakarta

[18] Tahang, Hamzah. 2018. Valuasi Ekonomi Ekosistem Mangrove Kabupaten Sinjai. Torani : JFMarSci. Volume 1 (2) June 2018: 71-80.

[19] Wagiu. M. 2011. Dampak Program Reklamasi Bagi Ekonomi Rumah Tangga Nelayan di Kota Manado. Vol. VII-1. April 2011. 